\title{
PEREMPUAN PEMENANG PEMILUKADA STUDI PERSPEKTIF GENDER DAN MELURUHNYA BUDAYA PATRIARKIDI PROPINSI JAWA TIMUR
}

\author{
Hj. Nurul Azizah \\ Lecturer Dacwah Faculty \\ at Institut Agama Islam Ibrahimy
}

\begin{abstract}
This article discusses the winner of the election of women as a gender perspective studies and studies fading patriarchal culture in the province of East Java. The purpose of the study is; (1). Explores the political motives of candidates, kandidasi process, support election management bodies and CSOs, and the issue of gender equality in the nomination, and political context that allows the emergence of female kandidasi process. (2). Get an overview of the political profile candidates, kandidasi process, the role and support of election management bodies and the $\mathrm{CSO}$, and the issue of gender equality in the nomination, and political context in the kandidasi process. (3). Interpret the presence of women in the election. The results of this study indicate that changes in the local political order decentralization followed by the application of the system of regional head election (election) directly, the more open structure of opportunity for women from various backgrounds to exist in the political space. If the existence of women in kandidasi lawmakers have increased, not the case in the election candidates are still relatively new.
\end{abstract}

Keywords: women, elections, gender, patriarchal culture

\begin{abstract}
Abstrak: Artikel ini membahas tentang perempuan pemenang pemilukada sebagai studi prespektif gender dan kajian meluruhnya budaya patriarki di Propinsi Jawa Timur. Rumusan masalah secara spesifik adalah; (1)Mempertanyakan motif politik kandidat dalam pemilukada. (2) Mempertanyakan keterkaitan isu kesetaraan gender dalam penominasian perempuan.; (3) Mempertanyakan proses kandidasi di partai politik dan jalur perseorangan. Adapun tujuan penelitian adalah; (1). Mengeksplorasi motifpolitik kandidat, proses kandidasi, dukungan lembaga penyelenggara pemilu dan CSO, dan isu kesetaraan gender dalam penominasian, dan konteks politik yang memungkinkan munculnya proses kandidasi perempuan. (2). Mendapatkan gambaran tentang profil politik kandidat, proses kandidasi, peran dan dukungan lembaga penyelenggara pemilu dan CSO, dan isu kesetaraan gender dalam penominasian, dan konteks politik dalam proses kandidasi tersebut. (3). Memaknai kehadiran perempuan dalam pemilukada. Signifikansi Penelitianini adalah (1).Rekomendasi untuk bahan perbaikan UU Pemilu khususnya yang menyangkut pemilukada dan UU Kepartaian; (2).Rekomendasi implementasi gender mainstreaming sebagai pencerminan pelaksanaan MDGs di Indonesia; (3).Rekomendasi strategi perempuan dalam kandidasi.Hasil Penelitian ini adalah; Perubahan tatanan politiklokal era desentralisasi yang diikuti dengan pemberlakuan sistem pemilihan umum kepala daerah (pemilukada) secara langsung, makin membuka struktur kesempatan bagi perempuan dari berbagai macam latar belakang untuk eksis dalam ruang politik.Jika eksistensi perempuan dalam kandidasi anggota lembaga legislatif telah makin meningkat, tak demikian halnya dalam kandidasi pemilukada yang relatif masih baru.
\end{abstract}

Kata Kunci: perempuan, pemilukada, gender, budaya patriarki 


\section{PENDAHULUAN}

Kehadiran sosok perempuan dalam panggung kontestasi politik Indonesia, baik pada pemilihan umum (pemilu) nasional maupun pemilihan umum kepala daerah (pemilukada) di daerah-daerah, kian tampak nyata. Kehadiran sosok perempuan itu tak bisa disangkal dan dipungkiri telah ikut meramaikan dan mewarnai dinamika politik.

Di daerah-daerah di mana pemilukada berlangsung sejumlah nama dan gambar tokoh perempuan muncul terpampang di ruang-ruang publik: disosialisasikan! Mereka menawarkan diri dan/atau ditawarkan sebagai alternatif pemimpin pemerintahan, berusaha memberi dan menumbuhkan harapan, dan tidak jarang memancing serta menjadi bahan perbincangan di berbagai kalangan.

Di antara sosok-sosok yang tampil ada yang sekadar meramaikan sampai pada tahapan nominasi, ada yang berhasil lanjut ke tahap kandidasi, bahkan ada yang telah berhasil memenangi kontestasi. Kehadiran sejumlah sosok perempuan dalam kontestasi politik di daerah-daerah dapat dikatakan sebagai fenomena baru, seiring dengan arus demokratisasi yang kian menguat hingga ke daerah-daerah.

Boleh jadi fenomena ini merupakan kecenderungan yang akan terus menguat, sebagai buah dari terus menguatnya gerakan dan tuntutan, serta meluasnya kesadaran tentang kesetaraan gender. Ruang dan jabatan politik kian terbuka, tidak boleh lagi ditutup-tutupi, tidak boleh lagi diperuntukkan eksklusif bagi laki-laki, dan tidak boleh ditabukan bagi perempuan.Perempuan berhak dan berpotensi memberikan kontribusi di arena politik.

Namun demikian, tetap saja fenomena makin banyaknya sosok perempuan dalam kontestasi politik di daerah telah memancing diskusi, perdebatan, dan tak jarang masih menyisakan keraguan, khususnya yang terkait dengan kapasitas kontributif perempuan dalam memajukan demokrasi, mengendalikan dinamika politik, dan mempercepat peningkatan kesejahteraan rakyat.

Tampilnya sosok politisi perempuan baik dalam politik lokal maupun kontestasi pemilukada di Indonesia ini bukanlah fenomena yang unik.Seperti diutarakan oleh Manuell Castells ${ }^{1}$ dalam The Power of Identity bahwa transformasi politik dunia menjelang abad ke-21 salah satunya ditandai oleh fenomena runtuhnya tatanan patriarki (the end of patriarchy) di berbagai belahan dunia.

Keruntuhan patriarki disini bukan semata-mata dalam pengertian tampilnya perempuan di wilayah publik mengimbangi dominasi laki-laki baik dalam jumlah maupun kapasitas, namun secara mendasar lebih mengarah 
pada perubahan fundamental formasi sosial politik dan budaya baik dalam ranah privat maupun publik yang menempatkan dominasi kaum laki-laki dalam pembagian kerja dan peran.

Dalam konteks ini maka ranah politik yang selama ini dimaknai sebagai dunia laki-laki, baik dalam pengertian dipenuhi oleh aktifitas kaum laki-laki, maupun dipengaruhi oleh karakter maskulinitas, mengalami transformasi besar-besaran yang tidak saja menempatkan hadirnya kaum perempuan namun juga tampilnya diskursus feminis dalam arena politik.

Kenapa perempuan perlu masuk politik?Perempuan memiliki kebutuhan-kebutuhan khusus yang hanya dapat dipahami oleh perempuan sendiri karena pengalaman hidup dan kondisi biologisnya. Dengan jumlah keterwakilan yangmemadai di lembaga eksekutif dan legislatif, diharapkan perempuan mampu memberi perhatian lebih pada permasalahan perempuan yang kerap dilupakan laki-laki.

Studi yang dilakukan Bank Dunia menunjukkan adanya kaitan erat antara keterwakilan perempuan di parlemen dengan penurunan kasus korupsi.Angka korupsi dinegara-negara yang keterwakilan perempuannya tinggi, dalam legislatif maupun eksekutif, sangat kecil.Negara-negara Skandinavia dengan keterwakilan perempuan lebih dari $40 \%$, kemakmuran dan kesejahteraan rakyat lebih baik serta diiringi pemerintahan yang lebih efisien.

Di Indonesia harapan serupa muncul, yaitu bagaimana perempuan bisa membawa perubahan dalam peta serta diskursus politik yang ada.Karena itu munculnya sejumlah perempuan kandidat dalampemilukadapemilukada di Tanah Air mendapat perhatian khusus. Perhatian serta perdebatan yang muncul menyentuh beragam isu,yang spektrumnya mencakup soal-soal 'kepantasan sosial' hingga yang berdimensi substantif dan kompetensi kepemimpinannya.

Berbagai perdebatan, yang sebagian direkam dalam liputan media massa, barangkali sekadar fenomena permukaan yang mengekspresikan betapa kompleksnya kaitan antarfaktor dan variabel yang mempengaruhi proses pempromosian keterlibatan perempuan dalam politik dan memposisikannya setara dengan lakilaki, yang sebelumnya telah sangat lama mendominasi dan menjadikan politik sebagai domain yang terkesan androsentris, macho, dan maskulin.

Secara normatif dan empiris perlu terus dikaji, seberapa jauh upaya perekayasaan institusi-institusi politik demokratis - seperti pencantuman kuota perempuan dalam undangundang pemilu danundang-undang kepartaian - telah berhasil membuka akses politikbagi perempuan. Seberapa jauhkah telah mengubah suasana danproses politik ke arah makin ramah 
terhadap permasalahan, peran,dan kontribusi perempuan.

Perlu lebih dicermati, apakah kebijakanformal telah mulai meluruhkan kendala-kendala struktural dankultural bagi peningkatan peran perempuan dalam politik. Sebaliknya, apakah perempuan sendiri telah makin banyak yang tergugah,termotivasi, terpanggil, berambisi, dan berhasil meningkatkan keterampilan politik dan jejaring politik, serta membangun danmemobilisasi basis dukungan politik, sehingga merasa telah makin siap berkompetisi dengan politisi laki-laki? Benarkah akseptabilitas terhadap perempuan dalam politik telah meningkat, atau hanya sekadar euforia, bahkan "kegenitan" atau "jebakan politik"? Apakah aksesibilitas perempuan dalam pemilukada berelasi signifikan dengan keterwakilan perempuan? Menurut kajian Dahlerup ${ }^{2}$, keterwakilan perempuan dalam politik tak bisa dilepaskan kaitannya dengan empat jenis perubahan.

Pertama, perubahan institusional/ prosedural; yang merujuk pada tindakantindakan untuk mengubah sifat institusi sehingga menjadi lebih "ramah perempuan". Perubahan-perubahan kultural, seperti sensitivitas yang besar terhadap gender harus disertai pulaoleh perubahan-perubahan prosedural yang dirancang untuk menjembatani perempuan dalam perpolitikan. Peningkatan sensitivitas gender bukanlah semata-mata persoalan melibatkan perempuan, tetapi juga sensitivitas bahwa perempuan sebagai katagori universal yang mempunyai pengaruh desisif terhadap kehidupan perempuan, sama seperti apa yang mereka lakukan terhadap kehidupan laki-laki.

Kedua, perubahan representasi yang melibatkan tindakan-tindakan khusus untuk menjamin keberlanjutan dan peningkatan akses perempuan. Perubahan ini menyangkut dorongan terhadap kandidat perempuan, penggunaan secara sadar tentang kapasitas model peran, memajukan legislasi kesetaraan gender, dan perubahan-perubahan yang layak dalam undang-undang pemilihan dan kampanye pemilu.

Ketiga, dampak/pengaruh terhadap keluaran (output) teruta mamerujuk pada "feminisasi" legislasi dan keluaran kebijakan lainnya. Seberapa jauh undang-undang dan kebijakan dibuat atau dipengaruhi oleh kehendak dan kepentingan perempuan. Perubahan ini mencakup pecantuman isu-isu perempuan dalam agenda dan menjamin agar seluruh proses legislasi selalu "ramah perempuan" dan responsif gender.

Keempat, perubahan diskursus yang melibatkan perubahanperubahan dikursus politik bahwa perempuan berpolitik adalah sebuah konsep yang wajar sebagaimana laki-laki berpolitik. 


\section{PEMBAHASAN}

\section{Kajian Pustaka}

Dinamika perkembangan wacana politik feminis sejak tahun 1990an telah menempatkan interaksi antara agensi perempuan dan institusi negara pada posisi yang signifikan. Setelah pada era sebelumnya gerakan perempuan memandang institusi negara secara skeptis sebagai institusi yang merawat, mempertahankan dan memelihara dominasi patriarki dalam arena politik, maka sejak era 1990-an terjadi pergeseran signifikan saat munculnya kesadaran politik untuk melakukan transformasi politik di level institusi negara agar lebih sensitif terhadap kepentingan kaum perempuan dan munculnya kesadaran akan kesetaraan gender diperjuangkan oleh agensi politik yang memperjuangkannya.

Sejalan dengan pentingnya merebut ruang pemaknaan dan penguatan kebijakan berbasis kesetaraan gender dilakukan di level institusi negara inilah Barbara Hobson ${ }^{3}$ menekankan diskursus politik feminis dalam konteks perjuangan untuk menghadirkan kepedulian (struggle forrecognition). Politik kepedulian di sini hadir dalam konteks historis, penyebaran diskursus, struktur kesempatan politik yang tersedia, kebijakan dan pelembagaan politik.

Pada saat bersamaan interaksi antara peran agensi politik dan kekuasaan dalam konteks politik gender memiliki tujuan untuk memastikan siapakah dan kebijakan seperti apa yang harus diakui dalam konteks bernegara (who andwhat gets recognized). Untuk memahami proses politik kepedulian sebagai agenda politik kesetaraan gender, maka ruang lingkup dari penelitian ini akan melihat bagaimana elit politik perempuan melakukan interaksi dengan gerakan sosial, publik dan partai politik untuk melakukan pembingkaian gagasan (framing process) berbasis kesetaraan gender yang akan mereka perjuangkan dalam proses kandidasi pada pemilu kepala daerah.

Sebagaimana teori proses pembingkaian isu, David Snow ${ }^{4}$ (2004) mengutarakan bahwa perspektif proses pembingkaian (framingprocess perspective theory) berhubungan dengan bagaimana makna yang dihadirkan oleh agensi dalam arena politik tidaklah secara alamiah muncul dan hadir namun pemaknaan tersebut adalah bagian dari proses konstruksi sosial yang muncul dari berbagai pengalaman baik dalam perjumpaan politik dan proses kontestasi dan negosiasi yang dibangun saat agensi politik melakukan interaksi politik baik dalam perjumpaannya dengan kekuatan politik, gerakan sosial dan organisasi masyarakat sipil maupun konstituen.

Dalam proses pembingkaian makna, maka makna itu sendiri tampil sebagai bagian dari proses politik yang 
berjalan secara dinamis. Dalam konteks keterhubungan antara proses kandidasi politisi perempuan dan gagasan kesetaraan gender, maka secara dinamis teori framming process akan dapat membaca bagaimana kandidat politisi perempuan mengkonstruksikan gagasan, ide dan makna yang diperjuangkan dalam proses politik yang dilakukan ketika bertemu dengan kekuatan-kekuatan politik sebagai pendukungnya maupun saat berkontestasi dengan pesaing politiknya.

Teori framming process dari David Snow ini dapat bertemu dengan teori pembingkaianmakna dari Barbara Hobson ${ }^{5}$.Menurut Hobson politik kepedulian (recognition politics) menempatkan bagaimana interaksi antara peran agensi politik dan kekuasaan dalam kontekssiapakah dan apakah yang diakui.Hal ini terkait dengan subyek politik yang seharusnya mendapatkan pengakuan dan isu-isu serta agenda apakah yang seharusnya diakui untuk diperjuangkan dalam arena politik.

Selanjutnya, menggunakan pendekatan teori proses politik dan struktur kesempatan politik (political process and political opportunitystructure theories) yang beberapa diantaranya dikembangkan oleh Hanspieter Kriesi dan Douglas Mc. Adam menjadi penting untuk menjelaskan kemunculan perempuan dalam pemilukada. Teori ini mencoba untuk memperlihatkan bagaimana aktivitas politik agensi dalam memaknai aktivitas mereka, strategi yang mereka lakukan maupun agenda politik mereka sangat ditentukan oleh kesempatan yang dihadirkan oleh struktur politik baik dalam konteks konfigurasi elit politik maupun kekuatan politik yang ada maupun dinamika kelembagaan politik ditingkat nasional maupun lokal yang dapat menghambat atau memberi kesempatan bagi aktivitas politik yang dilakukan oleh agensi politik.

Dalam konteks proses kandidasi politik perempuan, maka teori struktur kesempatan politik maupun proses politik ini sangat berkaitan dengan bagaimana pemaknaan agensi politik perempuan terhadap proses politik yang terjadi, agenda politik yang mereka perjuangkan maupun strategi politik yang dikedepankan sangat berhubungan dengan konteks politik dan struktur politik yang terbangun.

Penelitian ini juga menggunakan pendekatan perspektif gender sebagai struktur sosial yang digunakan oleh Barbara J. ${ }^{6}$,pengertian tentang gender sebagai struktur sosial dipahami dalam konteks hubungan interaktif antara struktur dan agensi dalam pemahaman teori strukturasi dari Anthony Giddens. ${ }^{7}$ Giddens memandang bahwa relasi antara struktur dan agensi tidaklah berlangsung melalui determinasi penuh struktur atas 
segenap aktivitas dari agensi, namun ketika tindakan agensi memiliki karakter reflektif dan bebas maka relasi antara agensi dan struktur berada dalam hubungan interaktif dan saling membentuk.

Struktur sosial memiliki tendensi untuk membatasi maupun memberdayakan agensi, sementara pada sisi lain tindakan reflektif agensi ikut membentuk struktur sosial yang ada. Memahami relasi gender dalam pengertian struktur sosial adalah melakukan analisis bagaimana hubungan relasi kekuasaan berbasis gender dalam ruang ekonomi, sosial dan politik memberdayakan dan/atau membatasi peran-peran agensi politik (perempuan kandidat) dalam proses politik kontestasi pemilukada, serta selanjutnya juga mengkalkulasikan bagaimana inisiatif dan tindakan politik yang dijalankan oleh agensi kandidat memberikan implikasi terhadap relasi gender sebagai struktur sosial politik, terutama pada saat prosesi pemilukada dijalankan.

Dari berbagai penelitian mengindikasikan bahwa pertimbangan gender, ${ }^{8}$ dalam politik pemilu, menentukan inisiasi agensi (perempuan kandidat) untuk memutuskan memasuki arena politik tersebut atau tidak.

\section{Bahan dan Cara Kerja}

Penelitian Eksploratif-Kualitatif,
Penelitian diawali dengan pertanyaan apa, mengapa dan bagaimana Nyai pesantren perempuan maju dalam pemilukada. Peneliti menduga perempuan pasti memiliki keinginan atau dorongan internal dan eksternal untuk kandidasi; bagaimana mereka sampai diusung oleh partai politik atau maju proses kandidasi yang diikuti perempuan.

Akhirnya peneliti memutuskan pendekatan yang memungkinkan untuk mencari jawaban atas pertanyaan tersebut dengan mengekplorasi pertanyaan-pertanyaan tersebut kepada perempuan dan Nyai pesantren sebagai pemenang pemilukada, pasangan calon, keluarga calon dan tim sukses.

Dan eksplorasi fakta hanya dimungkinkan melalui penelitian kualitatif.Artinya bahwa peneliti memahami perspektif subyek penelitian atau informan, bagaimana subyek penelitian memahami tindakan dan makna dalam konteks sosial mereka. Dalam mempersepsi realitas secara ontologis peneliti berasumsi bahwa realitas terbentuk secara obyektif dan apa adanya dan berwajah jamak.

Sedangkan secara epistemologis, peneliti berasumsi bahwa proses interaksi dengan fenomena yang dipelajari menjadi sangat penting. Oleh sebab itu keterlibatan langsung peneliti melakukan indept interview, mengamati dan melakukan observasi lapangan, berbaur dengan beberapa anggota 
masyarakat, merupakan cara untuk bisa mengumpulkan data secara detail. Ketika Peneliti akan membangun interaksi dengan para perempuan pemenang, tim sukses dan pasangan kandidat, dengan menggunakan bahasa personal informan, bahkan menggunakan bahasa-bahasa informal dari informan.

Desain Penelitian di penelitian ini adalah pendekatan kualitatif maka rancangan penelitian lebih terbuka dan relatif tidak terstruktur, dan menghindari konsep dan teori pada tahap awal. Penelitian ini sejak awal akan lebih banyak difokuskan pada temuan-temuan tertentu, lokalistik dan spesifik sehingga bisa menggambarkan konteks-konteks politik lokal dalam pemenangan Nyai pesantren dan perempuan di pemilukada. Dengan demikian teori bukan sebagai landasan pembuktian tertentu, tetapi hanya digunakan sebagai kerangka berpikir saja untuk menjelaskan sebuah fenomena obyektif.

Unit Analisa berguna menjawab problem penelitian, maka peneliti menempatkan aktor politik, proses politik dan konteks lokal sebagai unit yang dianalisa. Aktor politik dianalisa dari aspek profil kandidat yang menyangkut latar belakang, motivasi kandidat, modal sosial, modal politik kandidat dan dukungan keluarga. Proses politik dianalisa untuk menjawab dinamika interaksi antara kandidat (aktor) dengan institusi (Parpol, CSO, KPUD). Konteks Politik lokal dianalisa untuk menjawab apakah konteks lokal telah mendorong dan memungkinkan munculnya keberanian perempuan untuk maju dalam kancah politik yang biasanya diwarnai dengan pertunjukan ketrampilan politik termasuk dengan cara-cara yang paling kasar sekalipun. Dalam kancah ini ditampilkan contohcontoh penyelenggaraan pemilukada yang paling dramatis, kontroversial dan serta universal kemampuan perempuan mengorganisasi diri untuk maju dalam pemilukada.

Perempuan pemenang pemilukada adalah sebagai Subyek Penelitian. Peneliti memutuskan untuk memilih 6 perempuan yang menang sebagai Kepala Daerah maupun Wakil Kepala Daerah Kabupaten/ Kota di ajang pemilukada di Propinsi Jawa Timur, baik yang diusung oleh parpol atau melalui jalur perseorangan. Dalammemilih perempuan kandidat untuk subyek penelitian peneliti menggunakan kriteria sebagai berikut:

Pertama, peneliti sengaja memilih para perempuan yang mampu maju sebagai kandidat karena peneliti berharap mampu mengeksplorasi motif dan kepentingan perempuan untuk mencapai tangga kekuasaan politik.

Kedua, peneliti memilih Nyai pesantren dan perempuan pemenang pemilukada baik pada posisi bupati dan wakil bupati,wali kota dan wakil wali 
kota karena keduanya membutuhkan energi "perjuangan" baik modal sosial, politik maupun modal ekonomi untuk meraih kekuasaan.

\section{HASIL DAN KESIMPULAN}

Dari dinamika kandidasi perempuan dalam pemilukada langsung di wilayah Jawa Timur, dapat disimpulkan betapa perempuan kandidat tak pernah bisa terlepas dari hambatan tradisionalnya di ranah domestik. Dalam hal ini, sebagian besar perempuan kandidat tak memiliki kemampuan untuk menjadi individu yang otonom.Upaya meyakinkan keluarga inti (suami dan anakanak)dengan durasi waktu yang bervariasi, dari cepat hingga cukup lama, bisa dimaknai sebagai masih kukuhnya pembagian peran publik dan privat dalam struktur keluarga.

Mengurus keluarga cenderung dianggap sebagai femaletask daripada male task, sehingga ijin dari suami dan anaknya mutlak diperlukan bagi perempuan untuk maju dalam proses kandidasi. Sedangkan laki-laki, jika maju dalam proses kandidasi dipersepsi hanya perlu "memberitahu" pada keluarga inti daripada meminta ijin. Sehingga, secara psikologis perempuan kandidat akan merasa terbebani bila tak mendapat dukungan keluarga intinya.

Secara khusus, memang ditemukan perbedaan sikap dukungan suami terhadap perempuan kandidat.
Bagi perempuan kandidat yang suaminya berprofesi sebagai politisi, dukungan itu nyaris seketika dan cepat.Sementara bagi perempuan kandidat yang suaminya berprofesi sebagai non-politisi, dukungan tersebut tak serta-merta datangnya, bahkan dalam beberapa kasus cenderung muncul penentangan. Dukungan suami akhirnya didapat melalui proses persuasi yang memakan waktu. Selanjutnya, perempuan kandidat cenderung kerap dan/atau mudah dimanipulasi oleh para politisi laki-laki yang sudah lebih lama menjadi pemain politik.

Banyak perempuan kandidat yang dieksploitasi kemampuan finansialnya daripada diapresiasi kemampuan kepemimpinan dan manajerialnya.Walaupun memang kemampuan dan kemandirian ekonomi dapat menopang kandidat dalam kandidasi. Mengacu pengalaman pemilukada di wilayah Jawa Timur, sebagian besar perempuan kandidat, baik sebagai calonbupati/walikota/ papan satu ataupun wakil bupati/ walikota/papan dua, memang memiliki kemampuan finansial yang sangat kuat.

Minimal perempuan kandidat memiliki kemampuan memobilisasi sumber dana dari para pihak yang berkepentingan pada kandidasi tersebut. Latar belakang mereka sebagai pengusaha atau istri pengusaha atau istri pejabat, menjadi modal utama 
mereka untuk membiayai proses kandidasi. Dalam beberapa kasus, perempuan kandidat justru nyaris berperan sebagai "mesin ATM" bagi pasangannya yang kebanyakan lakilaki.

Kebutuhan akan kemampuan finansial mengakibatkan arena kontestasi didominasi oleh hadirnya para perempuan pengusaha yang merangkap sebagai politisi. Berikutnya, hasil penelitian ini menyimpulkan bahwa sebagian besar perempuan kandidat maju dalam proses kandidasi melalui kendaraan partai atau gabungan partai. Amat sangat terbatas yang melalui kendaraan independen. Padahal, proses seleksi dan nominasi perempuan kandidat oleh partai politik atau gabungan partai dalam pemilukada cenderung berlangsung elitis, sentralistik, dan tertutup.

Tidak ada prosedur yang transparan, predictable, dan membuka ruang afirmasi untuk peran serta perempuan. Akibatnya, proses kandidasi sulit diantisipasi oleh perempuan, apalagi bagi perempuan yang tak memiliki dana memadai untuk kandidasi. Penelitian ini menemukan bahwa pasangan perempuan kandidat dalam proses kandidasi sebagian besar adalah politisi atau birokrat.Sebagian besar pasangan mereka adalah nonincumbent. Sedikit sekali yang berpasangan dengan incumbent. Adapun pola pasangannya yaitu perempuan- lelaki atau lelaki-perempuan.

Selanjutnya, dalam keseluruhan dinamika proses kandidasiberkembang pola, bahwa dalam ruang publik yangterbuka dan terekspos, secara khusus perempuan kandidat diperlakukan layaknya stereotype perempuan (mis: harus diperlakukan halus, tak dimaki-maki, tak diperas, dsb.) oleh politisi laki-laki yang berkepentingan dengan pemilukada. Namun, di dalam ruang publik dan privat yang tertutupdan tak terekspos, perempuan kandidat diperlakukan justrusebagaimana layaknya perempuan diperlakukan secara domestik lengkap dengan tekanantekanan psikologis strukturalnya.

Seakan hal ini menegaskan betapa dinamikaproses kandidasi pemilukada adalah dunia laki-laki, danperempuan kandidat yang maju dalam proses kandidasiharus siap beradaptasi dengan dunia laki-laki tersebut. Termasuk dalam proses rapat dan negosiasi yang terkait dengan pemilukada cenderung dilakukan malam harihingga dini hari. Jadwal waktu yang semacam ini jelas taksensitif gender.Lebih khusus lagi, penelitian ini juga melihat hadirnya ironi dimana perempuan kandidat justru kerap mendapat resistensidari kalangan perempuan sendiri.

Tampaknya, fenomenaqueen-bee syndrome(sindroma yangmenggambarkan betapa kaum perempuan tak rela 
menerima perempuan lainyang dipersepsi lebih berprestasi darinya) juga merambahwilayah pemilukada. Bukan hanya itu, bahkan organisasi yang berbasis kepentingan gender tak banyak munculdan memberi dukungan kepada perempuan kandidat. Padahal, hadirnya organisasi perempuan yang mendukungperempuan kandidat dalam kandidasi pemilukada dapat membangun kepercayaan diri perempuan kandidat.

Akhirnya, terkait dengan lembaga penyelenggarapemilukada, relasi perempuan kandidat dengan KPUkabupaten/kota cenderung prosedural dan netral gender.Regulasi yang dibuat dalam batas kewenangan KPUsetempat diberlakukan seragam dan tak melihat adanya"gender difference", sehingga kebijakan menjadi sangatnetral gender yang tentunya merugikan bagi perempuan.

\section{Endnotes:}

1 Castells, Manuell. 1997. The Power of Identity. London and New York: Blackwell Publishing. Hal.134-138.

2 Dahlerup, Drude. 2006. Women Quotas and Politics. Routledge. New York

3 Barbara Hobson. 2003. Recognition Struggles And Social Movements; Contested, Identities, Agency And Power. UK: Cambridge University. Hal.6492

4 David A. Snow Dan Soule, Sarah Anne dan Kriesi, Hanspieter. 2004. The Blackwell Companion of Social Movements. London and New York:Blackwell Publishing.

5 Barbara Hobson. 2003. Recognition Struggles And Social Movements; Contested, Identities, Agency And Power. UK: Cambridge University. Hal.6492

6 Barbara J. Risman (2004) dalam Gender as Social
Structure: Theory Wrestling with Activism di Gender and Society, Vol. 18, No. 4 (Aug., 2004), halaman 429-450

7 Antony Giddens.1984.Structuration Theory. Relations Between Structur And Agensi.

8 Hermson, Paul S dan Lay, J Celeste, dan Stokes, Atiya." Women Running "as women": Candidate Gender, Campaign Issues, and Voter-Targeting Strategies". The Journal of Politics, Vol.65, No.1, Februari 2003.

\section{DAFTAR PUSTAKA}

Adam, Doug Mc dan Tarrow, Sidney dan Tilly, Charles. 2001. Dynamics of Contention. Cambridge UK: Cambridge University Press.

Castells, Manuell. 1997. The Power of Identity. London and New York: Blackwell Publishing.

Dahlerup, Drude. 2006. Women Quotas and Politics. Routledge. New York.

Hobson, Barbara. 2003. Recognition Struggles And Social Movements; Contested, Identities, Agency And Power. UK: Cambridge University.

Risman, Barbara J. 2004. Gender asSocial Structure: Theory Wrestling with Activism di Gender and Society, Vol. 18, No. 4 (Aug., 2004).

Snow, David A. Dan Soule, Sarah Anne dan Kriesi, Hanspieter. 2004. The Blackwell Companion of Social 
Movements. London and New York:Blackwell Publishing.

Hermson, PaulS dan Lay, J Celeste, dan Stokes, Atiya." Women Running "as women": Candidate Gender, Campaign Issues, and VoterTargeting Strategies". The Journal of Politics, Vol.65, No.1, Februari 2003.

Fox, Richard L, dan Lawless, Jennifer L,
2005. “ToRunorNottoRunforOffice: Explaining Nascent Political Ambition". American Journal of PoliticalScience, Vol.49,No.3,Juli2005.

http://www. antaranews.com/berita /1272893131/.

Jawa Pos. 8 Februari 2013

Jurnal Perempuan No. 63, 2009, Catatan Perjuangan Politik Perempuan. 